[Radiocarbon, Vol 22, No. 3, 1980, P 757-762]

\title{
STUDIES ON THE LOESS DEPOSITS OF THE KASHMIR VALLEY AND ${ }^{14} \mathrm{C}$ DATING
}

\author{
SHEELA KUSUMGAR, D P AGRAWAL, \\ and $\mathrm{R}$ V KRISHNAMURTHY
}

\author{
Physical Research Laboratory, Ahmedabad 380009, India
}

\begin{abstract}
The loessic deposits along with their palaeosols of the Kashmir Valley have been ${ }^{14} \mathrm{C}$ dated using both organic and carbonate fractions. The ${ }^{14} \mathrm{C}$ dates on both the fractions show good concordance. The ${ }^{14} \mathrm{C}$ dates indicate that the last deglaciation in Kashmir $\left(34^{\circ} \mathrm{N}\right.$ ) already started ca $18,000 \pm 1000 \mathrm{BP}$ at ca $1600 \mathrm{~m}$ and ca $15,000 \mathrm{BP}$ at ca $3000 \mathrm{~m}$ altitude and thus support the recent global evidence of deglaciation having started several millennia before the Holocene.
\end{abstract}

\section{INTRODUCTION}

The great boat-shaped Kashmir Valley $\left(33^{\circ} 30^{\prime}-34^{\circ} 30^{\prime} \mathrm{N}, 74^{\circ}-75^{\circ} 30^{\prime}\right.$ $\mathrm{E}$ ), with its variety of geomorphological features, provides a unique opportunity to study the Late Cenozoic palaeoenvironmental changes.

The valley floor has preserved a sequence of glacial and interglacial events in the form of Karewa deposits that once formed the bed of a Quaternary lake. Three main structural units have been recognized within the Karewa deposits which rest on Palaeozoic and Triassic rocks. The lower two lithologic units, the Lower and the Upper Karewa deposits, are fluvio-lacustrine, whereas the third unit comprises loessic deposits capping the Karewas in the valley.

The main aim of our multidisciplinary studies is to reconstruct the Quaternary palaeoenvironmental changes in the valley in a time-frame. Here we report only the results on the chronostratigraphy of the loessic deposits of the Kashmir Valley using ${ }^{14} \mathrm{C}$ dates.

The Kashmir Valley (fig 1) lying in a northwest-southeast direction, surrounded by the Himalayan ranges on the northeast and the Pir Panjal on the southwest, covers an area of more than $5000 \mathrm{sqkm}$. The Pir Panjals rose by several hundred meters during the early Pleistocene (or Pliocene) period, thus blocking the natural drainage, and giving rise to a large lake. The Pir Panjal side rose further during the Pleistocene period which resulted in the shifting and shrinking of the lake towards the Himalayan side. This phenomenon also caused the lake sediments on the Pir Panjal side to be lifted (de Terra and Paterson, 1939). During the II interglacial, further uplift caused the lake to drain out. The exposed lake sediments were called Karewa, which, in the local dialect, means a plateau.

\section{Loess and palaeosols}

The loess consists entirely of brown granular silts which do not show any depositional structure. The loess is well-graded and has a medium grain size ranging from $10 \mu$ to $50 \mu$ (Agrawal and others, in press). Scanning electron microscopy of these sediments shows clear loessic features (Pant, Agrawal, and Krishnamurthy, 1978). These loessic sediments possess the property to remain stable even in a vertical cutting (Bhatt, 1976).

In the southwestern (Pir Panjal) side of the Kashmir valley, these loessic deposits have 2 to 3 distinct palaeosols (at some sites we suspect there are more than 3 palaeosols) within them. The northeastern part 
also contains 2 to 3 palaeosols within the loessic deposits. On the Pir Panjal side there are some sites with loessic deposits 30 to $40 \mathrm{~m}$ thick, just above the gravel bed, whereas on the Himalayan side the loessic thickness is only 5 to $10 \mathrm{~m}$ and the deposit overlies the lacustrine beds of the Upper Karewa.

These loessic deposits apparently formed during the last glacial period which was marked by low temperatures and general aridity. The palaeosols within the loess, however, suggest relatively warmer and wetter climate, during which there was no fresh deposition and climatic conditions that favored soil formation. Our aim was to date these distinctive palaeosol forming events. Towards this end, palaeosol samples were collected from both flanks of the valley, the Himalayan and the Pir Panjal. The Himalayan side sites are Burzahom, Garhi, Olchibagh and Saki Paparian and the sites of Puthkhah, Pakharpur and Tsarar Sharif are on the Pir Panjal flank (fig 1; table 1). ${ }^{14} \mathrm{C}$ dates of the palaeosols are given in table 1.

\section{${ }_{14} \mathrm{C}$ dates}

We assayed ${ }^{14} \mathrm{C}$ dates on loess and palaeosol samples from the sites mentioned above. We labelled the palaeosols alphabetically for each site,

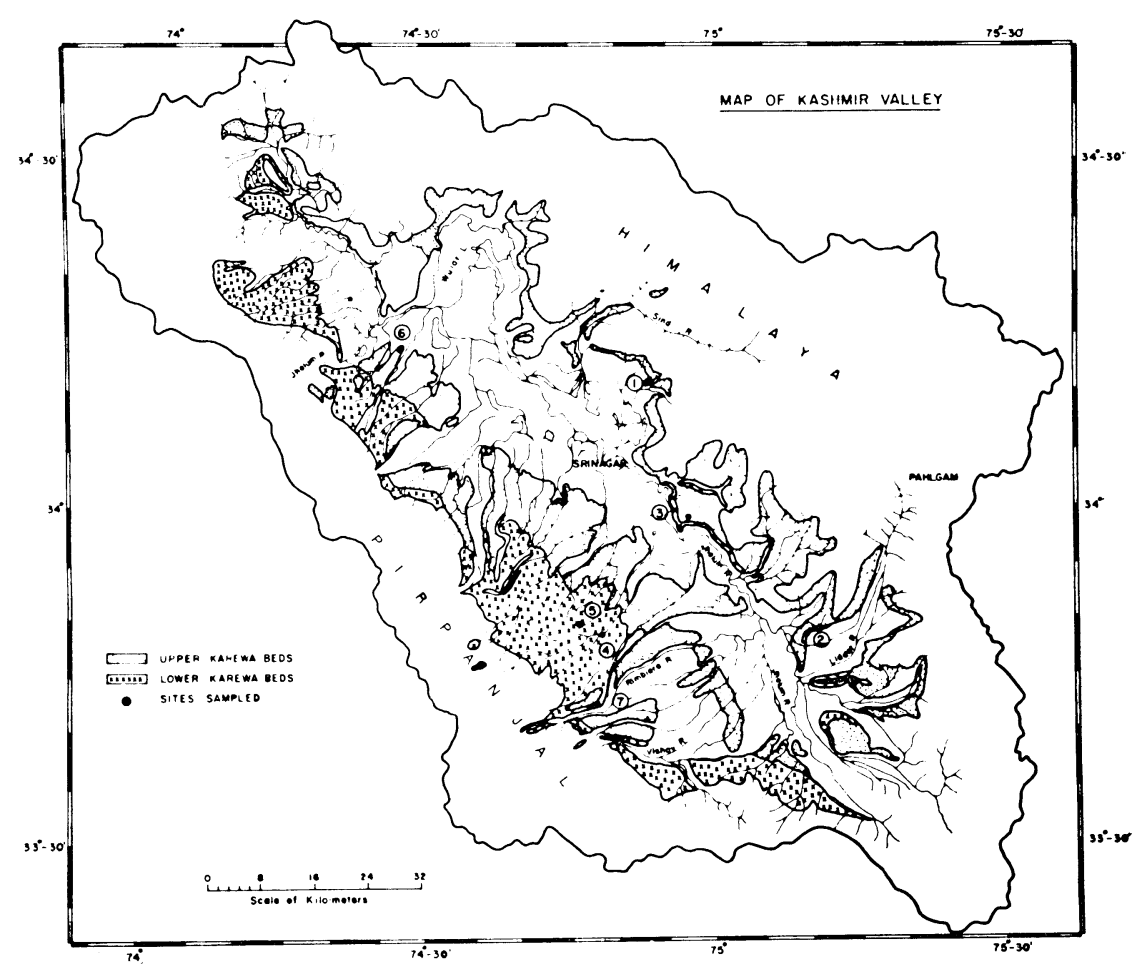

Fig. 1. Map showing sampling locations and Karewa distribution in the Kashmir Valley. Sites: (1) Burzahom; (2) Saki Paparian; (3) Olchibagh; (4) Pakharpur; (5) Tsrar Sharif; (6) Puthkah. 
TABle 1

${ }^{14} \mathrm{C}$ dates (on $\tau \mathrm{l} / 2=5568 \mathrm{yr}$ ) of palaeosols and loess from different sites in the Kashmir Valley*

\begin{tabular}{|c|c|c|c|c|}
\hline Site & $\begin{array}{l}\text { PRL } \\
\text { no. }\end{array}$ & Stratum & $\begin{array}{l}\text { Date in BP } \\
\text { on organic } \\
\text { carbon }\end{array}$ & $\begin{array}{l}\text { Date in BP } \\
\text { on carbonate }\end{array}$ \\
\hline Burzahom & 593 & Palaeosol A & $\begin{array}{r}+830 \\
18,890 \quad 750\end{array}$ & 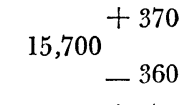 \\
\hline \multirow[t]{8}{*}{$\begin{array}{l}\left(34^{\circ} 10^{\prime} \mathrm{N}, 74^{\circ} 53^{\prime} \mathbf{E},\right. \\
\text { alt } 1620 \mathrm{~m}) \text { AMSL }\end{array}$} & 611 & $"$ & Nil & $\begin{array}{r}+570 \\
20,190 \quad 530\end{array}$ \\
\hline & 591 & $"$ & Nil & $\begin{array}{r}+1320 \\
-1130\end{array}$ \\
\hline & 590 & $"$ & 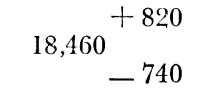 & 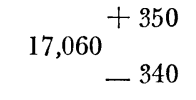 \\
\hline & 594 & " & Nil & $\begin{array}{r}+920 \\
20,430 \quad 820\end{array}$ \\
\hline & 495 & $"$ & $\begin{array}{r}10,320+170 \\
-160\end{array}$ & Nil \\
\hline & 500 & Loess A & Nil & $\begin{array}{r}26,450+890 \\
-800\end{array}$ \\
\hline & 585 & Palaeosol B & $>31,000$ & Nil \\
\hline & 586 & Palaeosol C & $>31,000$ & Nil \\
\hline $\begin{array}{l}\text { Garhi } \\
\left(34^{\circ} 10^{\prime} \mathrm{N}, 74^{\circ} 53^{\prime} \mathrm{E},\right. \\
\text { alt } 1620 \mathrm{~m}) \mathrm{AMSL}\end{array}$ & 592 & Palacosol C & $\begin{array}{r}26,340+2010 \\
-1610\end{array}$ & Nil \\
\hline Olchibagh & 597 & Palacosol A & Nil & $\begin{array}{r}24,960+1780 \\
-1460\end{array}$ \\
\hline $\begin{array}{l}\left(33^{\circ} 57^{\prime} 30^{\prime \prime} \mathrm{N},\right. \\
\left.74^{\circ} 56^{\prime} \mathrm{E} \text {, alt } 1600 \mathrm{~m}\right)\end{array}$ & 598 & Palacosol B & 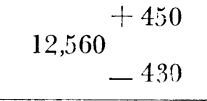 & $\begin{array}{r}+630 \\
-520\end{array}$ \\
\hline Saki Paparian & 595 & Palaeosol A & Nil & $\begin{array}{r}+2500 \\
-1900\end{array}$ \\
\hline $\begin{array}{l}\left(33^{\circ} 49^{\prime} \mathrm{N}, 75^{\circ} 7^{\prime} \mathrm{E},\right. \\
\text { alt } 1600 \mathrm{~m}) .\end{array}$ & 596 & Palaeosol B & $>31,000$ & $>31,000$ \\
\hline Puthkhah & 618 & Palacosol A & 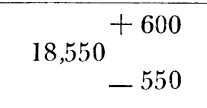 & $>31,000$ \\
\hline $\begin{array}{l}\left(34^{\circ} 14^{\prime} \mathrm{N}, 74^{\circ} 28^{\prime} \mathrm{E}\right. \\
\text { alt } 1600 \mathrm{~m})\end{array}$ & 617 & Palaeosol B & 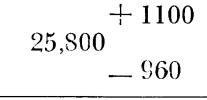 & $\begin{array}{r}28,560+1560 \\
-1300 \\
\end{array}$ \\
\hline $\begin{array}{l}\text { Pakharpur } \\
\left(33^{\circ} 48^{\prime} \mathrm{N}, 74^{\circ} 47^{\prime} \mathrm{E},\right. \\
\text { alt } 2000 \mathrm{~m}) .\end{array}$ & 627 & Palaeosol A & $\begin{array}{r}+1350 \\
-1160\end{array}$ & Nil \\
\hline Tsrar Sharif & 624 & Palaeosol A & $>35,000$ & Nil \\
\hline $\begin{array}{l}\left(33^{\circ} 50^{\prime} 30^{\prime \prime} \mathrm{N}\right. \\
\left.74^{\circ} 46^{\prime} \mathrm{E} \text {, alt } 2000 \mathrm{~m}\right)\end{array}$ & 625 & Palaeosol B & $>35,000$ & Nil \\
\hline $74^{\circ} 46^{\prime} \mathrm{E}$, alt $\left.2000 \mathrm{~m}\right)$ & 626 & Palaeosol C & $>35,000$ & Nil \\
\hline
\end{tabular}

* Carbonatcs were first removed to obtain date on organic fraction. 
following a stratigraphic sequence (top to bottom) at each section. At this initial stage of a 5-year project, it may be premature for us to stratigraphically correlate the palaeosols of the different sites. It must be noted that, eg, the Palaeosol A of Burzahom and Palaeosol A of Olchibagh have per se no implied stratigraphic correlation. We will try to correlate them only on the basis of ${ }^{14} \mathrm{C}$ dates.

The Burzahom ${ }^{14} \mathrm{C}$ dates $(\tau 1 / 2=5568)$ are quite consistent in ascribing the (top) Palaeosol A to ca $18,000 \pm 1000$ BP and the lower Palaeosol B and $\mathrm{C}$ appear to be $>31,000 \mathrm{BP}$. As the preliminary samples were small, they could not be counted in high pressure counter. Since Garhi and Burzahom are very close to each other we expected Palaeosol C of Garhi to correspond to Palaeosol $\mathrm{G}$ of Burzahom, stratigraphically but the former gave only an age ca $26,000 \pm 2000$ which is younger than expected. Because of its steepness, we could not sample any of the three palaeosols from the vertical section at Garhi. We could, however, collect Palaeosol C from an accessible slope but it appears that humic contamination from the decayed grass of the slope surface made the Palaeosol C date younger.

There was Neolithic (ca 4500-3500 BP) habitation debris on the top of both Burzahom and Garhi profiles. We also discovered Neolithic habitational debris above loessic deposits at Puthkhah. There were two palaeosols within it. Palaeosol A dates to ca 18,000 (organic fraction) and Palaeosol B to ca 26,000 (organic fraction). The dates conform with those of Burzahom Palaeosols A, but Palaeosol B seems to be younger than Burzahom B. It is significant to note that Neolithic habitations in the Kashmir Valley were located on the top of this Palaeosol A at Burzahom and other similar sites. Palaeosol A represents the beginning of the last deglaciation at ca $1600 \mathrm{~m}$ both at Burzahom and Puthkhah, respectively. It may correspond to the deglaciation which was in progress at Toshmaidan (Kashmir) at ca 15,000 вP at an altitude of ca $3120 \mathrm{~m}$ as inferred by Singh and Agrawal (1976) on the basis of ${ }^{14} \mathrm{C}$ dates of the pollen sequence there.

The Olchibagh dates (PRL-597 and -598) are a bit anamolous and need to be further checked. Palaeosol A did not yield any datable organic matter. Palaeosol B is anamolously younger than the Palaeosol A. As Palaeosol B sample did not belong to the same section from which Palaeosol A derived, and also as Palaeosol $\mathrm{B}$ did not have any significant loess cover, an admixture with the younger debris fallen from the adjacent section cannot be ruled out.

Dates are more consistent at Saki Paparian. Both Palaeosols A and B are $>31,000$ BP and therefore probably correspond with Palaeosol $\mathrm{B}$ and C of Burzahom. ${ }^{14} \mathrm{C}$ dates of Pakharpur top Palaeosol A is ca 28,000 вP while at Tsrar Sharif, all the Palaeosols A, B and C are >35,000 вP.

\section{DISCUSSION}

The significance of these dates is threefold. Firstly, we could compare dates based on both organic and inorganic fractions of the palaeosols. Except for PRL-598, and -618, all other dates on both organic and inorganic fractions showed good concordance. This can probably be taken as 
an indication that most of the carbonate samples were not subjected to any significant post-depositional chemical exchange and represent the date of formation of the relevant soil.

Secondly, in the geomorphological context of the valley, the dates fall in a distinct pattern. ${ }^{14} \mathrm{C}$ dates from the sites (Burzahom, Garhi, Saki Paparian, Puthkhah) falling in the area of the shrunken lake (Upper Karewa) have a distinct top palaeosol, datable to ca $18,000 \pm 1000 \mathrm{BP}$, and probably represent the onset of the last deglaciation. We mostly get uncontaminated samples of Palaeosol A where they are preserved under archaeological debris. Exposed Palaeosol A would be subject to the subsequent soil-forming processes, as climatic conditions since the last deglaciation have not changed much.

Palaeosol dates from the Pir Panjal side are devoid of the top palaeosol corresponding to Palaeosol A of Burzahom, etc (Upper Karewa lake). Both Palaeosol A of Pakharpur and Tsrar Sharif give dates $>35,000 \mathrm{BP}$ Since loess is deposited by aeolian agents, the absence of its top slice from the uplifted portions of the Lower Karewa sediments is enigmatic. One explanation could be that the wind activity could not lift its silt load beyond a height of $1600 \mathrm{~m}$ and, therefore, the portions of the exposed sediments that were tectonically uplifted above $1600 \mathrm{~m}$ did not receive any loessic deposits.

Thirdly, it is clear now that the last deglaciation in the valley goes back to ca $18,000 \pm 1000 \mathrm{BP}$, which is far beyond the traditional date of the inception of the Holocene. It is interesting to note that the ${ }^{14} \mathrm{C}$ dated pollen profile from Toshmaidan indicated that the last deglaciation was already in progress at ca $15,000 \mathrm{BP}$ at $3000 \mathrm{~m}$ altitude. Deglaciation at an altitude of $1600 \mathrm{~m}$ should be still earlier and therefore $18,000 \pm 1000 \mathrm{BP}$ is consistent with the Toshmaidan evidence. Recent work shows that the onset of deglaciation has been globally pushed back, far beyond the Holocene (Mercer, 1972). The Australian Academy of Science reports (AAS, 1976) "it is established that the last major deglaciation was taking place between 18,000 and 9000 years ago in all investigated parts of the world." From the South Asian context, our evidence, therefore, assumes great significance.

\section{CONCLUSION}

${ }^{14} \mathrm{C}$ dates on palaeosols show fair agreement between organic and inorganic fractions. In the Kashmir Valley, the onset of the last deglaciation at ca $1600 \mathrm{~m}$ is dated to $18,000 \pm 1000 \mathrm{BP}$ and at $3000 \mathrm{~m}$ to ca $15,000 \mathrm{BP}$. Further research is being undertaken to push back ${ }^{14} \mathrm{C}$ ages of palaeosols, by counting larger samples, up to 70,000 BP. Extensive sampling of palaeosols from exposures of loess sections all over the valley has also been initiated.

\section{ACKNOWLEDGMENTS}

R K Pant and V Nautiyal helped in the fieldwork and N B Vaghela gave laboratory assistance for which we are thankful. 
Agrawal, D P, Datta, P S, Kusumgar, Sheela, Mehrotra, N C, Nautiyal, V, Pant, R K, and Shali, S L, in press, Preliminary sedimentological studies on the Quaternary deposits of Kashmir: Himalayan Geology Seminar, 19th, Proc: Dehradun, in press.

Australian Academy of Sciences, 1976: Report of a Climatic Committee, Rept no. 21: Canberra, p 92

Bhatt, D K, 1976, Stratigraphical status of the Karewa group of Kashmir, India: Himalayan Geology, v 6, p 197-208.

Mercer, J H, 1972, The lower boundary of the Holocene: Quaternary Research, v 2, p 15-24.

Pant, R K, Agrawal, D P, and Krishnamurthy, R V, 1978, Scanning electron microscopy and other studies on the Karewa beds of Kashmir, India, in Whalley, W B, ed, Scanning electron microscopy in the study of sediments, 1977: Norwich, Geol Proc, p $275-282$.

Singh, G and Agrawal, D P, 1976, Radiocarbon evidence for deglaciation in northwestern Himalaya, India: Nature, v 260, no. 5548, p 232.

de Terra, $\mathbf{H}$ and Paterson, $\mathbf{T}$ T, 1939, Studies on the Ice Age in India and associated human cultures: Carnegie Inst Washington, Pub no. 493, p 354.

\section{DISCUSSION}

Fritz: As a comment to the preceding remark that the soil carbonate should always have less than "modern" ${ }^{14} \mathrm{C}$ concentrations one should mention that this is only the case if no exchange with the soil $\mathrm{CO}_{2}$ has taken place. If such exchange is possible, as will be the case in many soils, the ${ }^{14} \mathrm{C}$ content of the secondary soil carbonates could be very close to "modern".

Scharpenseel: Is the loess in the Kashmir valley periglacial in origin or blown out of the desert fringes?

Kusumgar: The loess is windblown in origin during glacial time.

Srdoc: I noticed much better agreement between very old organic and inorganic samples presented on your table and much less agreement among younger samples. Does it indicate that there might be a difference between organic and inorganic age, obscured by the very old age which is beyond the reach of ${ }^{14} \mathrm{C}$ method.

Kusumgar: One can see from the table, the dates of organic fractions and carbonate fractions show good concordance for Palaeosol-A (age range or $18,000 \mathrm{BP})$, which indicates that there is no significant post-depositional chemical exchange and represent the date of formation of the relevant soil. 